\title{
EFFECTS OF SOME ANTI-INFLAMMATORY DRUGS ON GAPILLARY PERMEABILITY OF THE GASTRIG MUCOSA IN THE RAT
}

\author{
KEIJIRO TAKAGI AND KOICHIRO KAWASHIMA \\ Department of Chemical Pharmacology, Faculty of Pharmaceutical Sciences, \\ University of Tokyo, Bunkyo-ku, Tokyo
}

Received for publication March 3, 1969

It has been reported that many anti-inflammatory drugs employed in the treatment of rheumatic disorders cause various gastrointestinal disturbances, such as haemorrhage and the development or reactivation of peptic ulcer. The mechanisms involved are not understood precisely, but they may include stimulation of gastric acid secretion and decrease in the resistance of the local gastrointestinal mucosa (1).

Serum proteins, albumin and globulin, have been found in gastric juice (2-4). A hypothesis that transudation of serum proteins from capillaries to the interstitial spaces and thence into the lumen of the stomach is a normal physiological process was proposed by Hollander and Horowitz (5). It has been shown that clinically a massive leakage of serum proteins into the stomach occurs often in gastric cancer, Menetrier's disease, and in some cases of gastric atrophy $(6,7)$. In addition, experimentally increased plasma output was seen in the canine stomach irrigated with fatty acids or salicylates (8).

In the present study, in order to find some relationships between gastric disturbances and chages in capillary permeability of the gastric mucosa, we investigated the effects of anti-inflammatory drugs, that is, aspirin, cinchophen, cortisone, indomethacin, and phenylbutazone, and three plant extracts which have anti-inflammatory or anti-peptic ulcer activities (9-12), on the output of plasma and the volume of gastric juice.

\section{MATERIALS AND METHODS}

Male Donryu strain rats weighing 190 to $240 \mathrm{~g}$ were fasted overnight and allowed free access to water. Coprophagy was prevented by using individual cages with widemesh floors. The stomach was exposed under light anesthesia with ether and the pylorus was tied off. The gastric lumen was washed with warmed saline (at $37^{\circ} \mathrm{C}$ ) by stomach tube until the washings were clear. The following three experimental groups $(\mathrm{A}, \mathrm{B}$ and $\mathrm{C})$ were employed.

A. In experiments investigating direct topical effects of drugs on the gastric mucosa, the stomach was filled with warmed drug solution $(2 \mathrm{ml} / 100 \mathrm{~g}$ of body weight). Physiological saline was administered as control. As an indicator of the changes in capillary

高木 敬次郎・川島 紶一郎 
permeability, 5\% of Pontamine Sky Blue 6BX (PSB) dye in a dose of $0.2 \mathrm{ml} / 100 \mathrm{~g}$ of body weight was injected into the femoral vein immediately after the administration of the drugs. Animals were sacrificed 2 hours after the dosing of the drugs and the dye, the stomach was removed and gastric juice was collected.

$B$. In the study on the effects of drugs administered intraduodenally on the normal mucosa, the stomach was filled with physiological saline warmed at $37^{\circ} \mathrm{C}$, and the drugs were administered intraduodenally. The controls received physiological saline. Three hours after the dosing of the drugs and the dye, animals were sacrificed. The stomach was removed and gastric juice was collected.

C. In experiments studying effects of drugs and plant extracts on the damaged mucosa, the stomach was filled with $0.7 \%$ acetic acid in $0.04 \mathrm{M}$ of $\mathrm{NaCl}$. The drugs were administered intraduodenally or intraperitoneally and plant extracts were administered intraduodenally. Two or three hours after the administration of the drugs and the dye, animals were killed. The stomach was removed and gastric juice was collected.

Analytical: The change in the volume of gastric juice was measured with a graduated cylinder and expressed as the difference between final and initial volume ( $\mathrm{ml}$ ).

The $\mathrm{pH}$ value of the gastric juice was measured with a glass electrode.

The amount of the dye in the gastric juice was determined as follows; after gastric juice was adjusted to $\mathrm{pH} 7.0$ with sodium hydroxide, $1 \mathrm{ml}$ of benzethonium chloride (Hyamine) solution ( $40 \mathrm{mg} / \mathrm{ml}$ ) and accurate amount of chloroform (one-half of the volume of gastric juice) was added. The mixture was agitated at $0^{\circ} \mathrm{C}$ for 1 minute by Waring blender, and then centrifuged at 3,000 r.p.m. for 10 minutes. The chloroform layer was withdrawn and spectrophotometric reading was made at 620 m $\iota$ against a chloroform blank with Hitachi Photo-electric Spectrophotometer EPU-2A. The results were expressed as $\mu \mathrm{g}$ of PSB per $100 \mathrm{~g}$ of body weight.

Drugs and plant extracts were suspended in physiological saline with a trace of polysorbate 80 .

The drugs: aspirin, cinchophen, cortisone acetate, indomethacin, and phenylbutazone.

The plant extracts: Crude Saikosides are a fraction from the root of Bupleum falcatum L. (Mishimasaiko). The fraction contains a considerable amount of saponins. The preparation of crude Saikosides was reported by Shibata (13). FM 100 is a fraction from licorice root (Glyzyrhiza glabra) and is dry brownish powder. The preparation of FM 100 will appear elswehere. Paeoniflorin is glycoside isolated from methanol extract of the root of Paeonia albiflora. The preparation of Paeoniflorin was reported by Shibata (14).

RESULTS

Effects of drugs administered into the stomach on the output of PSB and the volume of gastric juice (Table 1)

Aspirin $200 \mathrm{mg} / \mathrm{kg}(2 \mathrm{ml} / 100 \mathrm{~g}$ ) increased the output of PSB by $15 \%$. The response was statistically significant from that of the control $(P=0.05)$. Indomethacin $20 \mathrm{mg} / \mathrm{kg}$ 
TABLE 1. Effects of drugs administered in to the stomach on the output of PSB and the volume of gastric juice.

\begin{tabular}{|c|c|c|c|c|c|}
\hline Treatment & $\begin{array}{l}\text { Dose } \\
\mathrm{mg} / \mathrm{kg}\end{array}$ & $\begin{array}{l}\text { No. of } \\
\text { animals }\end{array}$ & $\mathrm{pH}$ & $\begin{array}{l}\text { Volume increment } \\
\mathrm{ml}\end{array}$ & $\begin{array}{l}\text { PSB output } \\
\mu \mathrm{g} / 100 \mathrm{~g} \mathrm{b.w} \text {. }\end{array}$ \\
\hline Control & & 9 & 1.5 & $3.1 \pm 0.5$ & $6.2 \pm 0.5$ \\
\hline Aspirin & 200 & 8 & 1.7 & $3.3 \pm 0.3$ & $10.1 \doteq 1.2^{*}$ \\
\hline Cinchophen & 200 & 10 & 1.7 & $3.2 \div 0.4$ & $6.7 \doteq 0.8$ \\
\hline Cortisone acetate & 50 & 10 & 1.7 & $2.9 \pm 0.5$ & $6.4 \pm 0.9$ \\
\hline Indomethacin & 20 & 10 & 1.4 & $4.2=0.4$ & $6.1 \pm 0.7$ \\
\hline Phenylbutazone & 200 & 10 & 1.6 & $2.9 \doteq 0.6$ & $6.3 \div 0.5$ \\
\hline
\end{tabular}

Values are mean + S.E.

* Statistically significant at $\mathrm{p}=0.05$.

slightly increased the volume of gastric juice. The other drugs did not affect both on the output of PSB and the volume of gastric juice.

Slight congestion in the gastric mucosa was found in the rat treated with aspirin at the end of the experiment.

Effects of drugs administered intraduodenally on the output of PSB and the volume of gastric juice in the normal stomach (Table 2)

Both aspirin $200 \mathrm{mg} / \mathrm{kg}$ and cinchophen $200 \mathrm{mg} / \mathrm{kg}$ reduced the output of PSB by $40 \%$ and the volume of gastric juice by $50 \%$. These values were statistically significant from those of the control $(P=0.01)$. Cortisone acetate $50 \mathrm{mg} / \mathrm{kg}$ slightly increased the output of PSB. Indomethacin $20 \mathrm{mg} / \mathrm{kg}$ and phenylbutazone $200 \mathrm{mg} / \mathrm{kg}$ had no effect on both the output of PSB and the volume of gastric juice.

TaBLE 2. Effects of drugs administered intraduodenally on the output of PSB and the volume of gastric juicc in the normal stomach.

\begin{tabular}{lrrrccc}
\hline \multicolumn{1}{c}{ Treatment } & $\begin{array}{c}\text { Dose } \\
\mathrm{mg} / \mathrm{kg}\end{array}$ & $\begin{array}{c}\text { No. of } \\
\text { animals }\end{array}$ & $\mathrm{pH}$ & $\begin{array}{c}\text { Volume increment } \\
\mathrm{ml}\end{array}$ & $\begin{array}{c}\text { PSB output } \\
\mu \mathrm{g} / 100 \mathrm{~g} \mathrm{~b} . \mathrm{w} .\end{array}$ \\
\hline Control & & 10 & 1.4 & & $6.2 \pm 0.5$ & $14.6 \pm 1.5$ \\
Aspirin & 200 & 10 & 1.7 & & $3.1 \pm 0.4 * *$ & $8.9 \pm 0.8^{* *}$ \\
Cinchophen & 200 & 9 & 1.6 & & $2.9 \pm 0.4^{* *}$ & $8.3 \pm 1.0^{* *}$ \\
Cortisone acetate & 50 & 10 & 1.4 & & $5.4 \pm 0.3$ & $19.0 \pm 3.0$ \\
Indomethacin & 20 & 9 & 1.3 & $6.3 \pm 0.4$ & $13.8 \pm 1.2$ \\
Phenylbutazone & 200 & 9 & 1.4 & $6.5 \pm 0.2$ & $13.9 \pm 0.6$ \\
\hline
\end{tabular}

Values are mean \pm S.E.

** Statistically significant at $\mathrm{p}=0.01$.

Effects of drugs administered intraduodenally on the output of PSB and the volume of gastric juice in the irritaled stomach (Table 3)

Aspirin $200 \mathrm{mg} / \mathrm{kg}$ and cinchophen $200 \mathrm{mg} / \mathrm{kg}$ reduced the output of PSB by $71 \%$ and $65 \%$, respectively in the rat stomach given $0.7 \%$ acetic acid. These values were statistically significant from that of the control $(\mathbf{P}=0.01)$. Cortisone acetate $50 \mathrm{mg} / \mathrm{kg}$ and phenylbutazone $200 \mathrm{mg} / \mathrm{kg}$ also reduced the output of PSB significantly $(\mathrm{P}=0.05)$. Indomethacin $20 \mathrm{mg} / \mathrm{kg}$ slightly reduced the output of PSB. The volume of gastric juice was reduced by $79 \%$ and $65 \%$ following the administration of aspirin and cinchophen, 
TABLE 3. Effects of drugs administered intraduodenally on the output of PSB and the volume of gastric juice in the irritated stomach.

\begin{tabular}{lrrrcc}
\hline \multicolumn{1}{c}{ Treatment } & $\begin{array}{c}\text { Dose } \\
\mathrm{mg} / \mathrm{kg}\end{array}$ & $\begin{array}{c}\text { No. of } \\
\text { animals }\end{array}$ & $\mathrm{pH}$ & $\begin{array}{c}\text { Volume increment } \\
\mathrm{ml}\end{array}$ & $\begin{array}{c}\text { PSB output } \\
\mu \mathrm{g} / 100 \mathrm{~g} \mathrm{~b} . \mathrm{w} .\end{array}$ \\
\cline { 2 - 6 } Control & & 9 & 1.3 & $4.8 \pm 0.4$ & $24.4 \pm 2.4$ \\
Aspirin & 200 & 10 & 2.2 & $1.0 \pm 0.3^{* *}$ & $7.0 \pm 0.8^{* *}$ \\
Cinchophen & 200 & 8 & 2.1 & $1.7 \pm 0.4^{* *}$ & $12.4 \pm 2.2^{* *}$ \\
Cortisone acetate & 50 & 10 & 1.3 & $4.7 \pm 0.4$ & $17.4 \pm 1.3^{*}$ \\
Indomethacin & 20 & 9 & 1.7 & $3.5 \pm 0.7$ & $18.7 \pm 2.0$ \\
Phenylbutazone & 200 & 10 & 1.6 & $3.7 \pm 0.5$ & $17.8 \pm 1.5^{*}$ \\
\hline Values are mean + S.E. & & & \\
* Statistically significant at $\mathrm{p}=0.05$. & \\
** Statistically significant at $\mathrm{p}=0.01$. &
\end{tabular}

respectively. The responses were statistically significant from that of the control $(P=0.01)$. Indomethacin and phenylbutazone slightly reduced the volume of gastric juice. The $\mathrm{pH}$ values of gastric juice were increased after aspirin and cinchophen.

Effects of drugs administered intraperitoneally on the output of PSB and the volume of gastric juice in the irritated stomach (Table 4)

A $22 \%$ decrease in the output of PSB was observed following the administration of cinchophen $100 \mathrm{mg} / \mathrm{kg}$ in the rat stomach given $0.7 \%$ acetic acid. The response was statistically significant from that of the control $(P=0.05)$. Aspirin $50 \mathrm{mg} / \mathrm{kg}$ did not affect the output of PSB. Indomethacin $10 \mathrm{mg} / \mathrm{kg}$ and phenylbutazone $100 \mathrm{mg} / \mathrm{kg}$ slightly reduced the output of PSB. Cinchophen, indomethacin and phenylbutazone reduced the volume of gastric juice significantly $(P=0.01,0.05)$. Slight peritoneal fluid exudation was seen in animals administered aspirin.

TaBLE 4. Effects of drugs administered intraperitoneally on the output of PSB and the volume of gastric juice in the irritated stomach.

\begin{tabular}{|c|c|c|c|c|c|}
\hline Treatment & $\begin{array}{c}\text { Dose } \\
\mathrm{mg} / \mathrm{kg}\end{array}$ & $\begin{array}{l}\text { No. of } \\
\text { animals }\end{array}$ & $\mathrm{pH}$ & $\begin{array}{l}\text { Volume increment } \\
\mathrm{ml}\end{array}$ & $\begin{array}{l}\text { PSB output } \\
\mu \mathrm{g} / 100 \mathrm{~g} \text { b.w. }\end{array}$ \\
\hline Control & & 10 & 1.3 & $3.3+0.3$ & $7.4 \pm 0.5$ \\
\hline Aspirin & 50 & 8 & 1.2 & $3.2 \pm 0.3$ & $7.5 \pm 1.3$ \\
\hline Ginchophen & 100 & 8 & 1.8 & $2.1+0.6^{*}$ & $5.8 \pm 0.7 *$ \\
\hline Cortisone acetate & 25 & 10 & 1.1 & $3.3 \pm 0.2$ & $8.2 \pm 0.8$ \\
\hline Indomethacin & 10 & 9 & 1.5 & $2.4 \pm 0.2^{*}$ & $6.0_{ \pm 0.7}$ \\
\hline Phenylbutazone & 100 & 8 & 1.6 & $2.0 \perp 0.3 * *$ & $6.2 \pm 1.0$ \\
\hline
\end{tabular}

Values are mean \pm S.F.

* Statistically significant at $\mathrm{p}=0.05$.

** Statistically significant at $\mathrm{p}=0.01$.

Effects of plant extracts administered intraduodenally on the output of PSB and the volume of gastric juice in the irritated stomach (Table 5)

The results obtained following the administration of these plant extracts were compared with those of atropine.

Atropine sulfate $5 \mathrm{mg} / \mathrm{kg}$ reduced the output of PSB by $35 \%$ and the voulme of gastric 
TABLE 5. Effects of plant extracts administered intraduodenally on the output of PSB and the volume of gastric juice in the irritated stomach.

\begin{tabular}{|c|c|c|c|c|c|}
\hline Treatment & $\begin{array}{c}\text { Dose } \\
\mathrm{mg} / \mathrm{kg}\end{array}$ & $\begin{array}{l}\text { No. of } \\
\text { animals }\end{array}$ & $\mathrm{pH}$ & $\begin{array}{l}\text { Volume increment } \\
\mathrm{ml}\end{array}$ & $\begin{array}{l}\text { PSB output } \\
\mu \mathrm{g} / 100 \mathrm{~g} \text { b.w. }\end{array}$ \\
\hline Control & & 10 & 1.4 & $4.9 \dashv 0.3$ & 27.5 上 3.4 \\
\hline Atropine sulfate & 5 & 10 & 2.5 & $0.9 \pm 0.1 * *$ & $17.7 \pm 2.1^{*}$ \\
\hline Crude Saikosides & 500 & 10 & 3.2 & $0.6 \pm 0.2^{* *}$ & $13.8 \pm 1.7^{* *}$ \\
\hline FM 100 & 400 & 10 & 1.5 & $3.6 \pm 0.4^{*}$ & $23.9 \pm 3.5$ \\
\hline Paeoniflorin & 1000 & 10 & 1.4 & $4.5 \doteq 0.5$ & $21.6 \pm 2.0$ \\
\hline
\end{tabular}

juice by $82 \%$. These values were statistically significant from those of the control $(P=0.05$, 0.01 respectively). Crude Saikosides $500 \mathrm{mg} / \mathrm{kg}$ reduced the output of PSB by $53 \%$ and the volume of gastric juice by $88 \%$. These values were statistically significant. FM 100 in a dose of $400 \mathrm{mg} / \mathrm{kg}$ reduced the volume of gastric juice significantly $(\mathrm{P}=0.05)$, but had no marked effect on the output of PSB. Paeoniflorin $1 \mathrm{~g} / \mathrm{kg}$ slightly reduced the output of PSB.

The $\mathrm{pH}$ values were markedly increased after atropine sulfate and crude Saikosides.

\section{DISCUSSION}

In the present study, PSB was used as an indicator of the amount of plasma which was shed in gastric juice. As Davenport (8) pointed out, it is difficult to maesure quantitatively the small amount of the dyc in gastric juice separating from mucus and debris, but we succeeded in extracting the small amount of the dye from gastric juice with chloroform completely. The optimal $\mathrm{pH}$ for extraction is 7.0 , where PSB complexes with Hyamine maximally and this complex is selectively soluble in chloroform. The dye concentration required for quantitative measurement is obtained by applying appropriate amount of chloroform to extraction. The increased plasma output from the gastric mucosa irritated with acetic acid determined in the present method coincides well with the results reported by Davenport (8) using intravenously administered ${ }^{51} \mathrm{Cr}$-albumine.

When the anti-inflammatory drugs were allowed to remain in contact with the gastric mucosa, only aspirin was found to produce gastric irritation (Table 1). On the other hand, the drugs administered intracluodenally reduced the output of plasma and the volume of gastric juice in the stomach irritated with acetic acid (Table 3). As acetic acid is known to increase the output of plasma as the result of gastric mucosal damage $(8,15)$, it seems that the drugs given systemically protect the gastric mucosa from damaging effect of acetic acid. In addition, aspirin and cinchophen reduced the normal plasma output (Table 2). These effects may be due either to lowered blood flow of the gastric mucosa or to the anti-inflammatory activities of the drugs. Atropine which reduced the output of plasma and the volume of gastric juice was reported to lower the blood flow of the gastric mucosa (16). And the association of gastrointestinal disoders with anti-inflamma- 
tory activities in several drugs was closely studied by Anderson (17). Anichikov and Zavodskaya (18) also reported that cinchophen and phenylbutazone reduced gastric secretion in rats, and that these drugs markedly retarded protcin synthesis in the gastric wall. The gastric mucosa in these states will be later impaired its resistance to acid-pepsin.

There was a fairly good correlation between reduction in the output of plasma and in the volume of gastric juice (Tables 2, 3, 4 and 5). Davenport $(8,15)$ proposed a theory that hydrogen ion moves back through the damaged mucosa and increases capillary permeability which leads to a plasma output from the gastric mucosa, and further suggested that acid itself is the initial stimulus for fluid production. Brodie and Chase (19) supported this theory and reported that gastric HCl played a causal role in aspirininduced gastric irritation in the rat. The present results also indicate that gastric acid may be responsible for the increase in the output of plasma. In addition, when the drugs were administered for 5 days in preliminary experiment, aspirin markedly increased both the output of plasma and the volume of gastric juice. The other drugs also slightly increased both of them. Gastric acid secretory mechanisms may be stimulated by later effects of the drugs, and the gastric mucosa which is already decreased in the local tissue resistance by retardation of the protein synthesis will become more susceptible to the incrcased acid-pepsin digestive activity.

Crude Saikosides and Paeoniflorin which have anti-inflammatory activities (9, 10) markedly or slightly reduced the output of plasma. FM 100 which has peptic ulcer inhibiting properties $(11,12)$ reduced the volume of gastric juice, but did not reduced the output of plasma so much. Further investigation is necessary for the explanation of effects of these plant extracts on the stomach.

So we can speculate that aspirin causes gastric disorders by two ways as follows; 1) when aspirin is allowed to contact directly with the gastric mucosa, it causes gastric irritation by the dircet topical damaging effects on the gastric mucosa, and 2) when aspirin is absorbed, it reduces mucosal resistance to acid-pepsin as the result of lowered gastric mucosal blood flow or the depression of fundamental metabolic and energy-producing mechanisms at sub-cellular level.

The other anti-inflammatory drugs may cause gastric disorders by the second mechanism.

\section{SUMMARY}

The effects of anti-inflammatory drugs, that is, aspirin, cinchophen, cortisone, indomethacin and phenylbutazone, on the output of plasma from the gastric mucosa and the volume of gastric juice were studied in the rat. Intravenously administered Pontamine Sky Blue dye was used as an indicator of the amount of plasma.

When the drugs were allowed to remain in contact with the gastric mucosa for 2 hours, only aspirin increased the output of plasma. In the normal stomach filled with physiological saline, aspirin and cinchophen administered intraduodenally reduced both the output of plasma and the volume of gastric juice. In the irritated stomach filled with 
$0.7 \%$ acetic acid all the drugs administered intraduodenally markedly or slightly reduced the output of plasma and the volume of gastric juice, when administered intraperitoneally cinchophen markedly reduced them. Three plant extracts, that is, crude Saikosides, FM 100, and Paeoniflorin were also tested.

There was a considerable correlation between the reduction in the output of plasma and in the volume of gastric juice.

Some possible relationships between drug-induced gastric disorders and the output of plasma and the volume of gastric juice were discussed.

\section{REFERENGES}

1) Sun, D.C.H.: Chemistry and Therapy of Peptic Ulcer, p. 105, Charles C. Thomas, Springfield (1966)

2) Cohen, N., Horowitz, i.M. and Hollander, F.: Proc. Soc. exp. Biol. Med. 109, 463 (1962)

3) Horowitz, M.I. And Hollander F.: J. biol. Chem. 236, 770 (1961)

4) Wetterfors, J., Gullberg, R., Liljedahl, S.-O., Plantin, L.-O., Birke, G. and Olhagen, B.: Acta med. scand. 168, 347 (1960)

5) Hollander, F. and Horowitz, M.I.: Gastroenterology 43, 75 (1962)

6) Glass, G.B.J. And Ishimort, A.: Am. J. dig. Dis. 6, 103 (1961)

7) Gabryelewicz, A. and Prokopczuk, J.: Gastroenterologia, Basel 105, 139 (1966)

8) Davenport, H.W.: Gastroenterology 50, 487 (1966)

9) Takagi, K. And Simbata, M.: in preparation

10) Takagi, K. and Harada, M.: in press

11) TAKagi, K. And Ishil, Y.: Arzneim.-Forsch. 17, 1544 (1967)

12) Ishir, Y.: Arzneim.-Forsch. 18, 53 (1968)

13) Shibata, S., Kitagawa, I. and Fujimoto, H.: Chem. Pharm. Bull. 14, 1023 (1966)

14) Shibata, S. and Nakahara, M.: Chem. Pharm. Bull. 11, 372 (1963)

15) Davenport, H.W.: Gastroenterology 46, 245 (1964)

16) Swan, K.G. and Jaconson, E.D.: Am. J. Physiol. 212, 891 (1967)

17) Anderson, K.W.: Non-Steroidal Anti-Inflammatory Drugs., p. 245, Excerpta Medica Foundation, New York (1964)

18) Anichikov, S.V. And Zavodskaya, I.S.: The Experimental Basis of Gastric Ulcer Pharmacotherapy, p. 112, Pergamon Press, Oxford (1968)

19) Brodie, D.A. and Chase, B.J.: Gastroenterology 53, 640 (1967) 